\title{
Stoička etika vrline i Rousseauova koncepcija građanske religije
}

Petar Jakopec*

\begin{abstract}
Sažetak
Stoicizam je, kao jedna od grčko-helenističkih škola, odigrao ključnu ulogu u povijesti filozofske misli, ali i u samom shvaćanjem etike. Stoičko se učenje, napose u razdoblju rimskog stoicizma (mladog stoicizma), usmjerilo na etička pitanja. Prema tome stoička etika kao zasebna filozofska disciplina stoicizma u biti je i nastala upravo u periodu mlade stoe u posljednjim stoljećima prije Krista te u prva dva stoljeća poslije Krista. Temelji stoičke etike počivaju u prevladavanju razuma nad strastima i emocijama. Za stoika etički je ideal postati i biti mudar, a konačni je cilj i smisao sljedbenika stoicizma ustrajati u duhu sveukupne filozofije stoicizma. Uzor za postizanje vrlina, odnosno životne harmonije s drugim ljudima stoici uvidaju u prirodi (kozmosu). U ovom radu nastoji se prikazati uloga i značenje etike u razdoblju mladog rimskog stoicizma. U samom promišljanju stoičkog etičkog učenja, žarište rada usmjereno je na ključne sastavnice stoičke etike, kao što su logos $i$ vrlina. Osim toga, u radu su radi zornijeg razumijevanja stoičke etike predstavljeni i najvažniji mislioci razdoblja mladog rimskog stoicizma: Seneka, Epiktet i Marko Aurelije. Naposljetku u radu se kritičkom rekonstrukcijom vrednuje Rousseauovo razumijevanje građanske religije kao svojevrsni pandan stoičkoj građanskoj religiji i etici.

Ključne riječi: rimski stoicizam, logos, vrlina, Seneka, Epiktet, Marko Aurelije, građanska religija, Jean-Jacques Rousseau
\end{abstract}

\section{Uvod}

Stoicizam je filozofsko učenje koje je nastalo oko 300. godine prije Krista. Školu je osnovao Zenon iz Kitiona na otoku Cipru. Naziv škole potekao je od mjesta sastajališta, koje je bilo natkriveni trijem (stoa) s ukrašenim slikama. Stoicizam je podijeljen u tri razdoblja. Prvo razdoblje starog stoicizma započelo je oko 300. godine prije Krista s njezinim začetnikom Zenonom i njegovim učenicima Kleantom i Krizipom. Drugo je razdoblje poznato kao srednji stoicizam, a

* Petar Jakopec, mag. phil., student poslijediplomskog studija filozofije na Filozofskom fakultetu Sveučilišta u Zagrebu. Adresa: Ivana Lučića 3, 10000 Zagreb, Hrvatska. E-pošta: petar.jakopec@gmail.com 
započelo je s Panetijem i Posidonijem polovicom 2. st. pr. Kr. Posljednje razdoblje stoicizma poznatije je kao razdoblje mlade stoe, odnosno rimskog stoicizma (Bošnjak, 1993, 290-292). ${ }^{1}$ U razdoblju starog i srednjeg stoicizma gotovo sva važnost pridavana je proučavanju gnoseologije i stvaranju stoičke logike. Tek u razdoblju rimskog stoicizma početkom 1. st. pr. Kr. važnost se započela pridavati etičkim problemima, odnosno kako umom, logosom prevladati patetičnost i afekte. Pripadnici stoicizma sustavno su izgradili svoju filozofiju i podijelili je na tri djela: na logiku, fiziku i etiku. Stoici su svoj filozofski sustav pokušali na slikovit način definirati tako da su logiku tumačili kao zaštitnu ogradu vrta, fiziku kao stablo koje raste u vrtu, a etiku kao plod (Kunzmann i dr., 2001, 55). Žarište ovog rada bazira se na etici u razdoblju rimskog stoicizma i njezinim temeljnim dijelovima kao što su vrlina te poimanje logosa i kozmosa u cjelini. Rad je podijeljen na tri poglavlja i nekolicinu podpoglavlja. U prvom poglavlju rada govori se o povezanosti čovjeka i njegove naravi u cjelini s kozmosom te se utvrđuje istinski smisao stoičke etike. Sljedeća tema predstavlja vrline i važnost logosa kao nosivog stupa etike stoika. Drugo poglavlje prikazuje filozofsko učenje trojice istaknutih predstavnika rimskog stoicizma Seneku, Epikteta i Marka Aurelija, koji su ujedno i obilježili to razdoblje u povijesti filozofije. Na kraju u trećem poglavlju prikazuje se kritičkom metodom Rousseauova koncepcija građanske religije kao svojevrsni pandan stoičkoj etici i civilnoj religiji. U radu se kreativnom izvornom interpretacijom ističe stoička etika te tumači sinteza prijelomnih misli istaknutih rimskih stoika i povezanost stoičke etike s Rousseauovim razumijevanjem religije.

\section{Ideja etike u rimskom stoicizmu}

Stoička etika svoje korijene i prva načela duguje prirodi, kozmosu i ljudima. Stoici svoje »postavke nastoje sustavno utemeljiti u panteističkom međuodnosu fizike, logike i etike« (Raunić, 2005, 52). Ljudska i kozmička priroda odnose se kao dio prema cjelini. Zenon, osnivač stoicizma, smatra »da svemir ima mnoge atribute koje posjeduju i ljudi, naročito racionalnost i čulno opažanje« (Gregorić i dr., 2005, 308). Čovjek za stoike u sebi posjeduje bitak koji označava pripadnost samomu sebi, pa time podupire stabilnost i sigurnost vlastite osobnosti. Pomoću duhovnih i tjelesnih vještina koje su u čovjeku urođene on sebe tada uspijeva izgrađivati, tako da je pojedinac u neprestanom kontinuitetu i usmjerenosti prema drugim pojedincima. Stoga je priroda za stoike usklađena cjelina koja racionalno i mudro upravlja svijetom. S druge strane, kozmos je jedinstvena cjelina ispunjena božanskom racionalnošću i djelotvornošću koja se očituje u sveukupnom svjetskom zbivanju. Kozmos stoici određuju u obliku neke vrijednosne ljestvice, koja se proteže od najjednostavnijih pa do najsloženijih predmeta, od zemlje i kamena, preko biljaka i životinja na koncu do čovjeka. Ukratko, temelj stoičke

1 Više o razdoblju i povijesti nastanka stoicizma: Bošnjak 1993. 
kozmologije čine logos i harmoničnost svijeta. Krajnji je cilj svakog stoika predati svoju sudbinu logosu, pa svoje praktično djelovanje stoici usmjeravaju prema transcendentalnomu naturalizmu, a rezultat je toga čestit život pojedinca. Iz te povezanosti proistječe i poštivanje općeg zakona uma (zdravog razuma), koji dobiva puninu u logosu. Ipak bitno je spomenuti da stoici iz »antičke tradicije preuzimaju heraklitovski pojam logosa ili svjetskog zakona, koji poistovjećuju s mnoštvom naslijeđenih pojmova: vatrom, dušom, umom, bogom, prirodom. Središnja stoička metafizička teza je da svjetski zakon, kao vječan, prirodan i istinski uman, neumitno vlada svim božanskim i ljudskim stvarima« (Raunić, 2005, 53).

Samoodržanje prvi je nagon koje živo biće ima već kao novorođenče, o čemu Hrizip u svojem djelu $O$ krajnjim ciljevima kaže:

Svakom je živom biću kao prvo urođeno vlastito postojanje i svijest o tome. Ta ne bi bilo vjerojatno niti da je priroda otuđila živo biće samom sebi, niti, kad ga je već stvorila, da ga nije ni otuđila ni učinila samom sebi sklonim. Preostaje, dakle, da kažemo da ga je stvorila takvim da bude samom sebi prijateljski naklonjeno. Jer živo biće otklanja tako od sebe sve što mu škodi, a teži za onim što mu je povoljno (Bošnjak, 1978, 128).

Priroda, odnosno kozmos, i čovjek kao dio tog kozmosa u kojem participira, teži očuvanju harmoničnosti svijeta, a vrlina mu služi kao sredstvo u tom naumu. Priroda

upravlja sveukupnošću prirodnih bića, i svim je bićima svojstvena neka usklađenost s prirodom. Ta je usklađenost spontana kod biljaka, kojima upravlja samo priroda. Kod životinja, utisak i poriv, koji im omogućuju da idu za onim što im je prikladno, nadopunjuju prirodu. Životinje, dakle, žive prema svojem porivu. Razum nadopunjuje poriv kod racionalnih bića, i zbog toga živjeti prema prirodi za čovjeka znači živjeti prema razumu, odnosno prema vrlini, koja je, kod čovjeka, savršenost razuma (Gourinat, 2014, 43).

Stoga usklađeno stanje duha za kojim pojedinac ipak treba težiti dovodi ga do istinske sreće. Vrlinu će pojedinac uspješno postići ako se odluči poštivati zdrava načela logosa. Prema Aristotelovoj Nikomahovoj etici

mi sve činimo poradi nekog dobra, no svako dobro je poradi nekog drugog dobra, i stoga se može ići od dobra do dobra sve do krajnjeg dobra, krajnje svrhe naših radnji, koju odabiremo zbog nje same a ne zbog nečeg drugog. Za Aristotela je ta svrha sreća, čiji je vrhunac kontemplativni život. Stoici preuzimaju tu ideju svrhe poradi koje činimo sve ostalo, ali niječu da je vrhunac hijerarhije kontemplativni život (Gourinat, 2014, 40).

\subsection{O vrlinama u stoicizmu}

Filozofija je za stoike honeste vivendi scientia ili učenje o vrlom životu i čestitoj usmjerenosti prema transcendenciji. Neuravnotežen dio duha je neki afekt koji je »nerazuman i protuprirodan pokret duše ili prekomjerno jak nagon« (Bošnjak, 1978, 130). Filozofija čovjeka prema stoičkom uvjerenju obnavlja i daje mu puninu života, liječi ga od robovanja strastima i afektima. Vrlina 
pretpostavlja i vježbanje i praksu, i ostvaruje se u djelovanju. Stoga je vrlina jedno umijeće življenja, te kao takva skup spoznaja koje se zajedno provode u djelo poradi nekog cilja koji je koristan za život. Vrlina je, dakle, vrsta spoznaje koja je popraćena praksom što nam omogućuje da živimo na harmoničan način i u skladu sa sobom samima i našim vlastitim razumom (Gourinat, 2014, 44).

Nadalje, prema stoičkom uvjerenju kad neki pojedinac posjeduje jednu vrlinu, on tada ostvaruje i druge vrline, a ako ne posjeduje ni jednu vrlinu, vrlo vjerojatno neće poznavati ni druge oblike vrlina. Uvjereni stoik svoju sreću »veže uz postizanje onoga što je odista dobro i izbjegavanje onoga što je odista loše, a to su vrlina i vrla djela odnosno porok i poročna djela. Dakle, on svoju sreću veže uz postizanje onoga što je do njega, nad čime on u potpunosti vlada « (Gregorić, 2006, 5). Dakle istinski i predani stoik živi jedino poštujući unutarnji glas savjesti, a što se uviđa i u »Senekinu djelu, k oblikovanju ideje moralne odgovornosti, savjesti i dužnosti« (Raunić, 2005, 54). Odgovornost prema dužnostima i postojanost u vrlinama odlika je stoika koja ga čini dostojnim da obavlja svoj životni poziv. Stanje unutarnjeg mira »stoici nazivaju apatheia, jer se u njemu nagon pokorava umu i ne pretvara se u pathos (afekt)« (Mikecin, 2003, 134).

Prema stoičkom uvjerenju pojedinac je u svojoj prirodi predodređen za vrlinu, no da bi pojedinac postao zbilja vrla osoba, potrebna je i sama ideja vrline. Albert Bazala sljedećim riječima definira vrli² život: »Krepost je umjeća. Sva umjeća sustav je načela trajno prisvojenih i zajedno uvježbanih. U koliko dakle ima djela na umovanju, krepost je načelo, u koliko je vježbom stečena sposobnost, u toliko je navika « (Bazala, 1909, 25). Stoici vrlo često naglašavaju da je vrlina poželjna radi sebe same, pa su dužnosti stoika činiti dobro, a izbjegavati zlo. Sve ono između je ravnodušno (adiaphora), jer niti šteti niti koristi. U kategoriju ravnodušnosti ulaze: život, zdravlje, ljepota, jakost, smrt, ružnoća te ostale ili slične životne značajke. Međutim, u poretku značajki ravnodušnosti neke karakteristike same po sebi mogu imati izraženiji intenzitet prikazivanja u svijetu.

\subsection{Utemeljenost etike u logosu}

Stoici su se u poimanju vrline i etike »uvelike oslanjali na Sokrata kakvoga nam prikazuje Platon u svojim ranim, tzv. 'sokratovskim' dijalozima, napose u dijalogu Protagora « (Gregorić, 2006, 8). U stoičkoj je etici napose prisutno Sokratovo učenje o vrlinama kao posebnom obliku znanja i prema tome Sokrat preporučuje zaživjeti one vrline koje vode do harmonije života, primjerice zdravi život ili prikladno ponašanje. Prikladne radnje bile bi one koje imaju svoje racionalno utemeljenje u nekom ophođenju i ne odudaraju od prirodnog ljudskog ponašanja. S druge strane, neprikladne radnje nemaju racionalno utemeljenje i nisu u skladu s ljudskom prirodom (Gregorić, 2006, 18). Prema stoicima život u skladu s prirodom moguć je jedino ako se zaista živi prema vrlini. Stoga je prirodni odabir života isključivo onaj koji je per se vrijedan i dostojan svakog čovjeka

2 Pridjev vrli dolazi od grčkog termina ó $\rho \varepsilon \tau \eta \dot{~(t a k o đ e r ~ p r i s u t a n ~ u ~ A r i s t o t e l o v o j ~ N i k o m a h o v o j ~ e t i c i) ~}$ koji se na hrvatski jezik prevodi kao vrlina. 
pa, na koncu, teleološki usmjeren prema zadovoljnomu i ispunjenomu životu (Inwood i Donini, 2005, 325). Za stoike je vrlo važno da čovjek zna razlikovati ispravno djelovanje od neispravnog djelovanja, jer će jedino tako ostvariti svoj život u punini. Neosjetilnost i nezainteresiranost prema vanjskim događajima i podražajima karakteristika je mudraca, naime »mudrac je slobodan i ma šta mu se zbilo u svakodnevnom životu, ništa ne može pokolebati njegovu krepost, znanje i sreću; njegova mudrost i njegova sreća samo su u njemu samom i svijet ga se ne tiče «(Krleža, 1969, s. v. stoicizam). Mudrac mora težiti za oslobođenjem od afekata i nastojati postići apatičnost (apatheia), pa mu je potrebno težiti vrlini, te na koncu postići i ravnodušnost (ataraxia). Sami afekti i emocije u čovjeku stvaraju trpljenje, stvarajući duh zaražen raznim duhovnim teškoćama. Modus vivendi za iskreno i pravilno djelovanje je živjeti po načelima savjesti, koja su ujedno slika općeg uma u čovjeku (logosa). Važno je gajiti vrlinu upravo poput običaja, tako da i sama vrlina na koncu postane u pojedincu zabilježena kao navika. U tom smislu Sorabji ističe da »ponekad indiferentne stvari koje imaju prednost igraju ulogu kod onih koji nisu na putu postizanja vrline « (Sorabji, 2016, 181). Načelo ravnodušnosti pojedinca dovodi do apatičnosti, koja je preduvjet za usklađivanje s logosom, odnosno vrlim životom.

Teorijom o sveopćem logosu stoici su isticali filantropiju i kozmopolitizam. Dakle, »kosmopolis je prije svega zajednica uma, a njezino političko ozbiljenje pretpostavlja jednakost svih ljudi u vrlini« (Mikecin, 2003, 135). Značajka kozmopolisa je novina koji su stoici unijeli u grčku filozofiju i istaknuli su se kao preteče moderne filozofsko-političke i religiozne misli. Stoici zagovaraju panteistički monizam, po kojem »su svi ljudi medjusobno srodni, jer svi imadu dijela na božanskom umu« (Bazala, 1909, 29), a na taj su način stoici izražavali ideju svjetskog građanstva. Ljubav koju ljudi moraju pružati treba biti usmjerena prema svim ljudima na svijetu, a ne na neku specifičnu državu. Prema čovječanstvu treba postupati kao prema jednoj zajednici (societas generis humani) (Bazala, 1909, 30). Stoici su prvi pokrenuli ideju jednakosti i slobode svih ljudi na Zemlji. Isticali su da je po prirodi svaki rođeni čovjek slobodan, a posebnu pozornost pridavali su ideji oslobođenja robova (napose Seneka). Biti kozmopolitskog svjetonazora u stoičkom smislu riječi značajka je da se prema svim ljudima valja odnositi kao prema sebi jednakima, kao prema braći i sestrama, jer se ne može osporiti činjenica da je svaka osoba dostojanstvena (Long, 2008, 51). Naime, stoička etika svoja metafizička načela pronalazi u transcendenciji, u logosu. Prema tome, »stoici utemeljuju vrlinu u određenju čovjeka kao bića koje ima logos. Eudaimonia je pojedinačno, unutarnje stanje čovjeka« (Mikecin, 2003, 134). Ideal čovjeka za filozofe stoike nalazi se u liku mudraca i vrlinom ispunjenog čovjeka. Sljedećim riječima Seneka Luciliju opisuje mudraca:

Što je zlo u mučenjima, što je zlo u drugim stvarima koje nazivamo nevoljama? Ovo, kako mislim, da se duša urušava i postaje lomljiva, da klone. Ništa od ovoga ne može se dogoditi mudrom čovjeku: stoji uspravno pod bilo kojim teretom. Ništa ga ne čini manjim; ni od čega od ovoga što mora podnositi ne zazire. Ne žali se što je snašlo njega ono što se može dogoditi svakom čovjeku. Poznaje svoje snage: on zna da je teretu dorastao (Seneka, 2013, 341-343). 
Mudrac je, pretpostavljaju stoici, uvijek dobre volje, nikad nije nezadovoljan, veseo je i uživa u dobru koje ima oko sebe. Na taj način čovjek zadobiva blaženost (eudaimonia), ništa više ne traži za sebe jer je zadovoljan onime što već posjeduje. Smrt je za stoike oslobođenje, naime oni smatraju kako posjeduju opravdani razlog za sve svoje čine djelovanja i potpuno se pouzdaju u ideju logosa. Svoj etički nauk stoici su naveliko nastojali provoditi u praktičnom životu. Pokoravali su se državnoj vlasti i zakonima ne želeći protestirati protiv njih. Stoička se svakodnevica sastojala od ispunjenog privatnog života, pa su često javne poslove prepuštali inerciji i ponekad ironiji sudbine. Stoga »stoička etika, kao praktična filozofija, u sebi sadržava odrednice o vrlini i sreći koje zahtijevaju temeljitu preobrazbu života nekog pojedinca, njegovih stavova, postupaka i samih motiva« (Annas, 2007, 71). ${ }^{3}$

\section{Najpoznatiji predstavnici mladog stoicizma}

U ovom poglavlju prikazat će se učenje i važnost istaknutih stoika u razdoblju rimskog stoicizma. Naime, oni sami svojim su djelovanjem zasluženo postali praktični filozofi, odnosno etičari koji su svu svoju filozofsku preokupaciju usmjerili na pitanje ispravnog individualnog vrlog djelovanja. Idejna vodilja u ovom poglavlju temelji se na razmatranju i osvjetljenju ključnih mislioca rimskog stoicizma: Seneke, Epikteta i Marka Aurelija, koji su ujedno i obogatili filozofiju u prvim stoljećima Rimskog Carstva poslije Krista.

\subsection{Seneka}

Seneka je rođen u Cordobi 4. godine poslije Krista, a umro je u Rimu 65. godine. Bio je Neronov osobni učitelj. Prema filozofiji se odnosio kao prema znanosti i praktičnoj djelatnosti. U obranu filozofije Seneka u šesnaestom pismu Luciliju tvrdi kako je neophodno baviti se filozofijom »bilo da nas sudbina privezuje neumoljivim zakonom, bilo da je bog kao sudac svega sve uredio, bilo da slučaj bez reda potiče i nabacuje ljudske stvari, filozofija nas treba štititi. Ona će nas poticati da se rado pokoravamo bogu, a sudbini prkosno; podučit će nas i to kako da slijedimo boga i podnosimo slučaj« (Seneka, 2013, 71). U praktičnoj djelatnosti Seneka filozofiji daje viši smisao jer, smatra Seneka, filozofija ne pronalazi bit u riječima, nego upravo u praktičnom djelovanju. Filozofija »ne služi za to da se čovjek provede u ugodnom zabavljanju, već oblikuje i obrazuje duh, uređuje život, sređuje naše postupke, pokazuje nam što treba raditi, a što ostaviti, sjedi na kormilu i vodi brod života kroz prolaze valovite bujice « (Bošnjak, 1993, 301). Prema Seneki, najvažnije je živjeti poštujući prirodna načela, a to je za Seneku, kao i za stoike, prihvatiti gnozu dualizma duše i tijela. Stoga Seneka ističe da je »tijelo teret, okov i tamnica duše, a duša je pravi čovjek i želi se osloboditi da postigne svoju čistoću « (Platz, 2005, 139). Seneka smatra da pojedinac treba pre-

3 Sve citate čiji su izvornici na stranom jeziku preveo je autor članka. 
ma sebi i drugima biti dobronamjeran. Zbog toga je tvrdio da čovjek »treba biti gospodar svojih afekata. Ono što dušu ne čini većom nije dobro« (Bošnjak, 1993, 302). Život u skladu s prirodom put je prema sreći i mudrosti. Senekin je ideal da pojedinac treba živjeti prema razlozima uma, a masa je glavni neprijatelj takvog života. Istinsko je uživanje u preziranju osjetilnih zadovoljstava jer su ona neka vrsta manifestacija boli. Prava sloboda postiže se ravnodušnošću prema sudbini (heimarmene), pa je stoga važno biti zadovoljan onim što čovjek jest i što na kraju ipak materijalnoga posjeduje. Na koncu, Seneka u svojem djelu O sretnom životu smatra da najviše »dobro leži u izboru dobra i stanju savršenog uma; kad je um ispunio svoju putanju i učvrstio se u svojim granicama, ostvaruje se najviše dobro i um više ne teži ni za čim drugim, jer ništa više ne može biti izvan cjeline, kao što ničeg nema onkraj kraja« (Seneka, 2007, 95).

\subsection{Epiktet}

Sljedeći je predstavnik mladog stoicizma Epiktet, koji je rođen 50. godine u Hijerapolu u današnjoj Turskoj, a umro je oko 138. godine. Doveden je u Rim kao rob, a kasnije je dobio status slobodnjaka. Proslavio se svojim djelom o moralu koje je poznato pod imenom Priručnik. Temeljno načelo Epiktetove filozofije može se podijeliti u dvije skupine: »a) ono što je u mojoj vlasti (mišljenja, želje, impulsi, odbojnosti); b) ono što nije u mojoj vlasti (što nisu naše aktivnosti, npr. tijelo, roditelji, rođaci, imanje, reputacija i sl.). Dobro i zlo stanuju isključivo u klasi koja je u našoj vlasti, jer ovise od naše volje « (Platz, 2005, 140). Pojedincu je važno poznavati što je u njegovoj moći, a što pak nije u njegovoj domeni. Prema tome bitno je, smatra Epiktet, da pojedinac prepoznaje svoje vlastite mogućnosti i granice, stoga je važno zadržati osobno mišljenje i postojano držanje (habitus). Epiktet je polazio od načela da su ideje prisutne u ljudskom umu i na pojedincu je da sam razluči hoće li ih ostvariti (Bobzien, 2002, 331). Prema tome Epiktet je kao stoik koji uviđa logos kao nosioca svega zbivanja prema božanstvu gajio poseban kult smatrajući da čovjek prema samoj religiji treba imati ispravne ideale te pravilno umjereno ophođenje, a što uključuje i pokoravanje vlastite volje bogu i sudbini (heimarmene). On ističe da božanstvo upravljaju svijetom, a proročišta nam olakšavaju neizvjesnost. Razboritost kao odlika pojedinca postaje vrlo bitna pa Epiktet u Priručniku tvrdi: »Ne traži da se stvari događaju onako kako želiš, nego ih želi onako kako se događaju, pa će ti sve ići glatko« (Gregorić, 2006, 49). Epiktet je isticao da je pojedincu potrebno potražiti sreću u svojem duhu te da se prema životu pojedinac treba odnositi kao Sokrat, kao filozof koji svim bićem želi spoznati istinu i živjeti po istini. Na koncu može se istaknuti da je Epiktet smatrao »kako je pojedinac građanin čitavog univerzuma. Štoviše univerzum je njegova istinska domovina koju ne smije zapostavljati već joj treba biti poslušan i pokoran, ako je potrebno i život dati« (Devine, 1970, 328). Ideja kozmopolitskog pojedinca, kao građanina svijeta i čitavog univerzuma, prisutna je u stoicizmu od samog zasnivanja te škole. Praktičnu i dovršenu filozofsku ideju kozmopolitskog čovjeka postavio je Marko Aurelije u spisu Samomu sebi, u kojem se ističe prisutnost logosa kao bitka života. 


\subsection{Marko Aurelije}

Imperator i filozof Marko Aurelije rođen je 121. godine u Rimu, u patricijskoj obitelji, a umro je oko 180. godine za vrijeme vojnog pohoda kod Vindobone. Bio je posljednji rimski car koji je širio granice Carstva. Napisao je i poznato djelo, za vrijeme osvajačkih pohoda, Samomu sebi. Marko Aurelije se ponajviše ističe

svojim stilom, punim bljeskova i jezgrovitih misli, te svojim oštrim uvidima u smrt, krhkost i nepostojanost ljudskoga života i slabosti tijela, svojim surovim opisima hrane i spolnosti što se izmjenjuju sa sposobnošću naziranja ljepote božanskog djelovanja čak i u pucketanju kore kruha i gnjiljenju voća, riječju, svojim posve osobitim načinom da umanji i uzdigne sve stvari, da ponizi čovjeka i uzvisi božanstvo, vraćajući nas našem skromnom mjestu u svemiru (Gourinat, 2014, 87-88).

Njegov je osnovni stav da je pojedincu potrebno živjeti u skladu s prirodom (logosom), a filozofija je jedina ispravna i prava vodilja u ovom životu. Duh treba uzdići iznad zadovoljstva i nezadovoljstva osjetila kako bi sam duh postao neovisan. Sve što se događa u skladu s logosom dobro je i nikako nije loše, pa tako ni sama pojava smrti. Važno je zadržati mir (ataraxia) u sebi jer je svijet vječna promjena, mijena, a sam je život kao »nabujala rijeka«. Priroda je središte svih zbivanja u svijetu, sve od nje polazi i završava u njoj. Sve je prolazno, a sretan je onaj pojedinac koji je dobrog raspoloženja i čistih namjera. Svaki se posao, smatra Marko Aurelije, i služba obavljaju zdravim razumom, a ne afektivno i odviše temperamentno. U djelu Samomu sebi Marko Aurelije ističe da »valja, ne samo disati zajedno sa zrakom koji nas okružuje, već i biti jedno s Duhom koji sve prožima. Duhovna snaga nije ništa manje razlivena u svemu te prožima svakog koji je umije udahnuti, kao što zrak prožima svakoga koji umije disati« (Marko Aurelije, 2001, 110). Stoga je ključna misao filozofije Marka Aurelija vjerovanje u Jedno. Drugim riječima, njegova ideja počiva u jednom jedinstvenom načelu, u monizmu. Štoviše, značajka je njegove filozofije predanost mnogoboštvu u religiji te obavljanje religijskih i državnih obveza koje su nužne za ugledan i pristojan odgoj svakog pojedinca (Copleston, 1988, 474-475). Ipak, Marko Aurelije donosi i svojevrsni pjesnički metafizički zaključak: »Sve što je u skladu s tobom, o Svemiru, slaže se i sa mnom! Ništa mi nije ni rano ni kasno što je za tebe u pravom trenutku. Sve što tvoja doba, Prirodo, donose, za mene je plod! Od tebe polazi sve, u tebi se nalazi sve i tebi se vraća sve. Jedan kaže 'o dragi Kekropov grade', pa zar ti nećeš reći 'o dragi grade Zeusa’? « (Marko Aurelije, 2001, 45). Pouzdanjem u raširenu gnozu prvih stoljeća poslije Krista, pa i samo shvaćanje Transcendencije prisutno u obrisima stoičke filozofije, Marko Aurelije se ipak istaknuo kao vješti car i vojskovođa, a napose kao originalan filozof stoičkog duha. Štoviše Marko Aurelije godine 176. osniva »u Ateni katedre filozofije za svaku od četiri glavne filozofske doktrine (platonizam, stoicizam, epikureizam, aristotelijanizam), čini se dvije katedre po školi« (Gourinat, 2014, 76). 


\section{Rousseauov koncept građanske religije kao pandan stoičkoj}

Rousseauov koncept građanske religije temelji se na ideji mnogoboštva koje je Rousseau uočio kod antičkih političkih zajednica. U tom smislu Rousseau razlikuje kako »Bog jednog naroda nije imao nikakva prava na druge narode. Poganski bogovi nisu bili ljubomorni bogovi; oni su međusobno podijelili carstvo svijeta « (Rousseau, 1978, 169). Uočavajući povijesnost religije kao prepoznavanje božanskih fenomena u svijetu i transcendentno djelovanje Boga u stvarnosti, Rousseau je nastojao protumačiti pojavu religije u političkoj zajednici. Kao primjer građanskog poštivanja religioznih običaja Rousseau smatra sljedeće: »Konačno, budući da su Rimljani sa svojim carstvom širili svoj kult i bogove, a često su i sami prihvaćali kultove i bogove poraženih, dajući i jednima i drugima pravo građanstva, narodi tog prostranog carstva neopazice su stekli mnoštvo gotovo posvuda istih bogova i kultova. Eto kako je konačno poganstvo u čitavom svijetu postalo ista religija « (Rousseau, 1978, 170). Rousseau, kao i stoici, uviđa nepobitnost poštivanja svakog čovjeka i religioznih fenomena i obreda radi samog opstanka čitave zajednice s konačnom svrhom da se istakne dostojanstvo svakog čovjeka. Ipak Rousseau čini podjelu religije na tri oblika. Prvi oblik religije je religija čovjeka koja je usmjerena na osobno iskustvo Boga i Rousseau takvu religiju smatra prirodnom. Drugi je oblik religije religija građana, koja je usmjerena štovanju državnih bogova te je takav oblik religije bio svojstven u prvim oblicima civilizacije. Treći oblik religije Rousseau naziva svećeničkom religijom, odnosno religijom koja zagovara zagrobni i zemaljski život (Rousseau, 1978, 171). Rousseau zagovara drugi oblik religije, te prema tome neophodnost štovanja državnih bogova. U tom smislu Rousseau ističe kako je »suveren dužan utvrditi pravila, ne tako točna kao religijske dogme, već kao osjećaje društvenosti bez kojih je nemoguće biti dobar građanin i vjeran podanik «(Rousseau, 1978, 174). Dodjeljujući političkoj zajednici ulogu stvaranja religijskih običaja Rousseau, na pragu stoika, religiji daje civilni status jer se na taj način učvršćuje i ističe nacionalni identitet političke zajednice i time zadobiva potpuna predanost i podložnost državnoj službi. Stoici su upravo u prvim stoljećima Rimskog Carstva nastojali širiti svoju etiku kao svojevrsni oblik građanske religije u kojoj su posebno istaknuli pokoravanje logosu, odnosno rimskim bogovima i državnoj službi. Stoička etika u tom je smislu i svojevrsni oblik građanske religije jer se odnosi na sve pojedince unutar političke zajednice, odnosno Rimskog Carstva, a s druge se strane Rousseauov pandan građanske religije jednako tako odnosi na sve pripadnike političke zajednice i od njih očekuje političku participaciju.

\section{Zaključak}

Stoici su za vrijeme stare, srednje i mlade stoe unaprijedili značenje i smisao filozofije tako da su raspravljali o čovjeku kao individui i njegovu odnosu prema transcendenciji, dakle, logosu. Svojstvenim etičkim načelima stoici su zagovarali vrlinom i razboritošću ispunjeni život. Međutim, život usklađen s prirodom izi- 
skivao je i određeni materijalizam, determinizam, ali i introspekciju. Značajka kozmopolitizma, koju su oni među prvima zastupali, posebice Marko Aurelije, postala je vrlo važna jer na toj ideji počiva suvremeno shvaćanje kozmopolita, odnosno svijeta bez fizičkih granica. Među predstavnicima mladog stoicizma postoji zajednička ideja o univerzalnoj etici i posebnoj ulozi pojedinca u svijetu. U Senekinom etičkom učenju mogu se uvidjeti tragovi platonizma jer je Seneka čvrsto zastupao ideju da je duša zarobljena u tijelu. Nakon Seneke, Epiktet je ustvrdio da čovjek može utjecati samo na događaje koji su u njegovoj domeni, odnosno da treba spoznati svoje mogućnosti i sposobnosti. Na koncu je Marko Aurelije, rimski vojskovođa i imperator, zaključio da je za čovjeka najbolje da sluša svoju savjest i pokorava se načelima logosa. Znamenita je, u etičkom učenju stoika u razdoblju mladog stoicizma, izuzetna religioznost. Naime, svoju su praktičnu filozofiju upravili prema transcendentnosti i poštivanju nadnaravnih zakona logosa koji upravljaju kozmosom. Ipak, važno je istaknuti da su stoici nastojali ostvariti praktičnu filozofiju u svijetu i na taj su način neizravno pokušavali učiniti društvo naprednijim, kako idejom o kozmopolitu, tako i učenjem o vrlom djelovanju. Stoička se etika može istaknuti svojom univerzalnošću, idejom mudraca, ali i idejom svijeta bez fizičkih granica (kozmopolita). Paralela stoičke etike sa Rousseauom je neophodna jer upućuje na Rousseauov koncept građanske religije i povlači za sobom reperkusije na sam koncept stoičke etike, koja prelazi u svojevrsni oblik državne religije u prvim stoljećima Rimskog Carstva. Na koncu, stoička je etika praktična filozofija, i od pojedinca očekuje živo i zbiljsko djelovanje te je normativnog karaktera jer teži harmoniji pojedinca s logosom i ispunjenje svih normi koje nalaže sama etika.

\section{Literatura:}

Annas, Julia (2007). Ethics in Stoic Philosophy. Phronesis, 52(1), 58-87.

Bazala, Albert (1909). Povijest filozofije: Svezak II.: Povijest filozofije helenističko-rimske: Filozofija u srednjem vijeku: Novija filozofija do Kanta. Zagreb: Matica hrvatska.

Bobzien, Susanne (2002). Determinism and Freedomin Stoic Philosophy. New York: Oxford University Press.

Bošnjak, Branko (1978). Filozofija od Aristotela do renesanse i odabrani tekstovi filozofa. Zagreb: Nakladni zavod Matice hrvatske.

Bošnjak, Branko (1993). Povijest filozofije: Razvoj mišljenja u ideji cjeline: Sv. 1. Zagreb: Nakladni zavod Matice hrvatske.

Copleston, Frederick (1988). Dimitrije Tasić (ur.), Frederik Koplston: Istorija filozofije: Tom I: Grčka i Rim. Beograd: Beogradski izdavačko-grafički zavod.

Devine, Francis Edward (1970). Stoicism on the Best Regime. Journal of the History of Ideas, 31(3), 323-336.

Gourinat, Jean Baptiste (2014). Stoicizam. Zagreb: Jesenski i Turk.

Gregorić, Pavel (2006). Uvod u stoičku etiku i Epiktetov nauk. U: Epiktet, Priručnik (str. 1-39). Zagreb: KruZak.

Inwood, Brad; Donini, Pierluigi (2005). Stoička etika. U: Pavel Gregorić, Filip Grgić i Maja Hudoletnjak Grgić (prir.), Helenistička filozofija: Epikurovci, stoici, skeptici (str. 307-369). Zagreb: KruZak. 
Krleža, Miroslav (ur.) (1969). Enciklopedija Leksikografskog zavoda. Zagreb: Jugoslavenski leksikografski zavod.

Kunzmann, Peter; Burkard, Franz-Peter; Wiedmann, Franz (2001). Atlas filozofije. Zagreb: Golden marketing.

Long, Anthony Arthur (2008). The Concept of the Cosmopolitan in Greek \& Roman Thought. Daedalus, 137(3), 50-58.

Marko Aurelije (2001). Samomu sebi. Zagreb: CID-Nova.

Mikecin, Igor (2003). Etičko opravdanje Rimskog Imperija. Sociologija i prostor: časopis za istraživanje prostornoga i sociokulturnog razvoja, 41(1/2), 131-146.

Platz, Slavko (2005). Povijest filozofije I: Stari vijek: grčka i rimska filozofija. Đakovo: Katolički bogoslovni fakultet u Đakovu.

Raunić, Raul (2005). Pretpostavke liberalnog razumijevanja čovjeka. Zagreb: Hrvatsko filozofsko društvo.

Rousseau, Jean-Jacques (1978). Rasprava o porijeklu i osnovama nejednakosti među ljudima: Društveni ugovor. Zagreb: Školska knjiga.

Seneka, Lucije Anej (2007). Dijalozi: O postojanosti mudraca: O providnosti: $O$ sretnom zivotu: Florilegij. Zagreb: Nova akropola.

Seneka, Lucije Anej (2013). Moralna pisma Luciliju: Svezak prvi: Pismo 1-81. Zagreb: Demetra.

Sorabji, Richard (2016). Emocije i duševni mir — od stoičke uznemirenosti do kršćanskog iskušenja. Zagreb: Sandorf \& Mizantrop. 
Stoic Virtue Ethics and Rousseau's Concept of Civil Religion

Petar Jakopec*

Summary

Stoicism, one among several Greco-Hellenistic schools, not only played a key role in the history of philosophical thought, but also in the shaping of our very understanding of ethics. Stoic teachings during the period of Roman Stoicism (early Stoicism) placed a special focus on ethical issues. Thus, Stoic ethics as a distinct philosophical discipline in fact came into being in the period of the early Stoa during the latter centuries before Christ and in the first two centuries after Christ. Fundamental to Stoic ethics is the subdueing of passions and emotions by means of reason. A Stoic's ethical ideal is to become wise and to be wise, while the ultimate goal and purpose of the followers of Stoicism is to endure in the spirit of its integral philosophy. The model for achieving virtue, that is, a life in harmony with other persons, is seen by Stoics as existing in nature (the cosmos). This article aims to demonstrate the role and meaning of ethics during the period of early Roman Stoicism. This reflection on Stoic ethical teaching is focused upon some key components of Stoic ethics, such as logos and virtue. Furthermore, for a clearer understanding of Stoic ethics, the article introduces the most significant thinkers of early Roman Stoicism: Seneca, Epictetus and Marcus Aurelius. Finally, a critical reconstruction will serve to assess Rousseau's grasp of civil religion as being a sort of counterpart to Stoic civil religion and ethics.

Key words: Roman Stoicism, logos, virtue, Seneca, Epictetus, Marcus Aurelius, civil religion, Jean-Jacques Rousseau

* Petar Jakopec, Post-Gradute Student of Philosophy, Faculty of Humanities and Social Sciences, University of Zagreb. Address: Ivana Lučića 3, 10000 Zagreb, Croatia. E-mail: petar.jakopec@gmail.com 